\title{
Role of Weather Factors and Wheat Varieties on the Occurrence of Leaf Rust of Wheat in Satna, M.P. India
}

\author{
Doomar Singh* \\ Department of Plants Pathology, Faculty of Agriculture Science and Technology, AKS \\ University, Satna-485001, Madhya Pradesh, India \\ *Corresponding author
}

\section{A B S T R A C T}

\section{Keywords}

Wheat; Leaf rust;

Temperature;

Rainfall; RH;

Varieties;

Resistance

Article Info

Accepted:

14 April 2021

Available Online:

10 May 2021
Weather data of February (III \& IV weeks) and March (I, II \& III weeks) during two cropping seasons (2018-19 and 2019-20) on the incidence of LR of wheat were recorded from Satna, M.P. to find out the effect of weather factors on disease development, its intensity and response of wheat varieties against LR under these weather factors. In cropping season 2018-19 (Feb. \& Mar. 2019) weather remained unfavourable (mean max., mean min. \& average RH of Feb. were 44.57, 18.36 \& $31.46 \%$ respectively \& of Mar. were $49.05,31.14, \& 40.09 \%$ respectively) and rainfall and cloudiness were very low for development of LR therefore, disease was not occurred. In cropping season 2019-20 (Feb. \& March 2020) mean max., mean mim. \& average RH of Feb. were 85.64, $39.21 \& 62.42 \%$ respectively \& of Mar. were 84.66, $39.09, \& 61.87 \%$ respectively were favourable for LR disease development therefore, disease was occurred in most of the varieties grown in the experiment. In the present study there were not more differences in mean mim., mean max. and average temp. (Feb. \& March) during both cropping seasons. Total rainfall in2018-19 (Feb \& March) was only $2.75 \mathrm{~mm}$. while in $2019-20$ (Feb. \& March) it was $41 \mathrm{~mm}$, very high as compared to Feb. \& March 2019 which increased the total RH for disease development. The most significant effect on the development of LR on wheat was high RH, amount of rainfall and number of days with precipitation during mid Feb. to mid-March. It was also observed that most of LR resistance was broken down by the favourable weather conditions. Only HI 1605, JW 3288, HI 1531, HI 1500, HI 8498, HI 8713, MP 1142, HD 2864, HI 1500, HI 8627, GW 322 and Sonalika were found resistant.

\section{Introduction}

Better crop production is not possible without favorable agrometeorological factors (temp., $\mathrm{RH}$, rainfall, light, wind velocity etc.) even agronomic practices like - soil, manure \& fertilizers, crop variety, time \& spacing, irrigation, weed management, crop protection etc. remain optimum. Meanwhile, "Agriculture is said to be a grate gamble" due to the complexity of agrometeorological factors. Farmers face a lot of problems due to 
these meteorological factors in crop production.

Environment plays an important role in disease development while soil and weather conditions influence the seasonal development and geographical distribution of plant diseases. The effects of environmental factors on plant diseases have been reviewed by Colhoun (1973). Further the influence of environment on the development and the control of disease have also been reviewed by McCartney in 1997. Host (plant species) is another important factor in development and control of plant diseases which allow or reject the pathogen to harbor on or in it for completion of its life cycle. Human being is not able to control the weather and dispersal of pathogen through wind and cyclonic rain but the susceptibility of host against any pathogen can be controlled through development of resistance against a particular pathogen.

Wheat (Triticum aestivum L.) is the plant ever to be cultivated and plays a key role in Man's economic and social development. Many wheat high yielding varieties which have been performing better in response to yield for many years suddenly fail due to adverse environmental/weather conditions. Though many biotic stresses obstruct wheat production, out of which rust diseases are best known as their devastating and widespread nature because these have caused epiphytotic conditions in India which have created famines in the country (Sleeman 1839; Joshi et.al. 1970; Joshi 1976; Joshi et.al., 1984a, 1985). However, the rust pathogens continue to affect production through the occurrence of new virulent races and adverse meteorological conditions that have led to the discontinuance of important varieties. Depending on the direction of wind spread of uredospores in each cropping year, wheat growing areas of the World are clustered in nine epidemiological regions. India is also one of these nine regions of leaf rust (LR) epidemics (CABI, 2012). In relation to meteorological factors, cyclonic storms from the way of Bengal in October and November, bring heavy rain in the central districts of Tamil Nadu, Andhra Pradesh and Orissa every year which carry uredospores of black and brown rusts of wheat from the southern hills to the central province of the country (Joshi, et. al. 1974; Nagarajan \& Singh, 1973, 1974; Joshi et.al. 1985; Bahadur, et al., 1994).Instead of dispersal of LR the amount of precipitation and number of rainy days also play an important role in disease development (Nagarajan and Joshi,1978a; Singh \& Tiwari,2001). The requirement of minimum, maximum and optimum temperatures for the germination of uredospores, growth of germ tubes, formation of appressoria, penetration and formation of sub stomatal vesicles have been best studied by many plant pathologists (Stubbs et al., 1986; Stuckey \& Zadoks, 1989; Singh et al., 2002; Riaz et al., 2013; Marsalis and Goldberg 2017). Leaf wetness and latent period is another factor for LR disease development (Stuckey \& Zadoks, 1989; Riaz et al., 2013; Marsalis and Goldberg 2017). Number of hours with temperature between 5 to $25^{\circ} \mathrm{C}$ and relative humidity $>87 \%$ are highly correlated and predicts LR infections with $89 \%$ accuracy.

Host (wheat varieties) is another important factor in the development of LR disease. Many resistant/tolerant wheat genotypes (varieties) have been developing against LR disease of wheat since 1960s for management of this devastating disease but due to continuous evolution of new races of the fungus, Puccinia recondite Rox. Ex Desm. and favourable weather conditions for the fungus (temp., relative humidity and rainfall during crop season) this resistance is broken down (Muhammad et al., 2015). The objective of this study was to identify the key weatherdisease links in Satna, M.P. This study was 
also attempted by employing effort that how LR epiphytotic correlated with weather factors.

\section{Materials and Methods}

Fifty notified, unnotified and local wheat varieties were collected from different sources. Seeds of collected varieties were sown manually on $15^{\text {th }} \& 25^{\text {th }}$ Nov. 2018 and 2019 respectively in the experimental field of plant breeding, AKS University, Satna. Each variety was sown in $2 \times 10 \mathrm{~m}$ size plot by maintaining isolation distance of $1 \mathrm{~m}$. The row-to-row distance was kept $25 \mathrm{~cm}$ and plant to plant distance $5 \mathrm{~cm}$. Recommended agronomic practices were followed to raise the crop as per the Vindhyanchal region. The objectives of the experiment were to determine the role of weather factors (temp., relative humidity and winter rainfall) and existed wheat varieties in the occurrence of LR disease in Vindhyanchal region and to determine the interaction of weather and existed wheat varieties in development of LR disease in the region. The experimental study was carried out during 2019-2020 crop season at the altitude above the sea level $315 \mathrm{~m}$ in the natural field conditions. The annual average rainfall is $1140 \mathrm{~mm}$. Nitrogen and phosphorus were applied at the rate of $100 \mathrm{~kg} / \mathrm{ha}$. and 80 $\mathrm{Kg} / \mathrm{ha}$. respectively. The soil of experimental field is calcareous with $\mathrm{pH}$ 7.5. The crop was irrigated three times according to critical stages of wheat except rainfall during the cropping season. The varieties used in the experiment were enlisted on the basic of year of release. Natural disease infection was observed after first sign of disease to till the dough stage of the crop (from first week of March to third week of March). The incidence of wheat LR can be calculated arbitrary according to Cobb, 1892; Horsfall and Barratt, 1945; Peterson et al., 1948 and Chester, 1950. Here I have estimated the incidence of LR as per Horsfall and Barratt, 1945 who gave 12- grade scale $(1=0 \%, 2=0-3 \%, 3=3-6 \%, 4=6-$ $12 \%, \quad 5=12-25 \%, \quad 6=25-50 \%, \quad 7=50-75 \%$, $8=75-87 \%, \quad 9=87-94 \% \quad 10=94-97 \%, \quad 11=97-$ $100 \%$ and $12=100 \%)$ and took into consideration the fact that the grades detected by human eye are approximately equal divisions on a log scale. The disease incidence was observed after first sign of disease (10 days after first winter rainfall i.e., first week of March) to till the dough stage of the crop (third week of March) in both cropping seasons (2018-19 \& 2019-20). All wheat varieties used in the experiment were tabulated on the basis of year of release and status of resistance (Table 2). Uredospores were observed by the compound microscope with $10 \mathrm{X}$ and $45 \mathrm{X}$ magnifications using cotton blue as stain. Since, the LR of wheat has intimate relation with weather factors (temperature, relative humidity and winter rainfall)which were obtained from observatory of AKS University and were calculated as mean; maximum, minimum temperatures and relative humidity (RH) of February (third and fourth weeks) and March (first, second \& third weeks) 2019 and 2020 (Table 1). These weather data were used in the establishment of relationship with development of LR disease by Nagarajan and Joshi (1978a); Stubbs et al., (1986); Stuckey \& Zadoks (1989); Singh et al., (2002); Riaz, et al., (2013); Marsalis and Goldberg (2017).

\section{Results and Discussion}

The disease was diagnosed on the basis of characteristics symptoms of LR that the uredia were confined only to leaves not on sheath and stem. They were not in rows or strips. Uredia were round to slightly oblong, brown and were irregularly scattered and some uredia were also in clusters only on the leaf blade (Fig. 1). The uredospores were brown to bright orange coloured, spherical with minutely echinulate walls (Fig. 2). The telia were not developed in most affected varieties but in few infected 
varieties they were developed on the lower surface of the leaf blade which were small, linear, dull black and covered by epidermis (Fig. 3). Weather factors (temperature, humidity and winter rainfall) played a crucial role in the incidence of LR. The disease was not observed during cropping season 2018-19 due to unfavourable weather factors for the disease while it was observed during cropping season 2019-20 due to favourable weather for the disease development (Table 1).

In present Rabi crop season (2019-20) weather conditions such as temperature and humidity (mean maximum, mean minimum $\&$ average) in February and March months remained optimum due to occasional winter rainfall for the development of LR (Table 1). Winter rainfall in February due to western disturbance brought the uredospores of Puccinia recondita Rox. Ex Desm. in the Vindhyachal region of MP. Occasional rainfall in March month (Table 1) predisposed the wheat crop and LR fungus for disease development.

These weather conditions became favourable for growth of germ tubes, formation of appressoria, penetration, formation of sub stomatal vesicle and pustules formation. In these favourable weather conditions, the LR was developed in most wheat varieties (Table 2) even in the varieties which were characterized as resistant against LR at the time of release by the plant breeders and have been performing better for last many years due to unfavourable weather for disease development. In present study it was also found that most of low yielding varieties like HI 1605, JW 3288, HI 1531 and HI 1500 were either immune or very resistant while most of high yielding varieties were found either moderately susceptible or very susceptible (Table 2). Weather data in table 1 show that in February 2019 the average relative humidity (III \& IV weeks) has been remained very low
$(31.46 \%)$ due to clear sky after winter rainfall $(2.75 \mathrm{~mm})$ in III week, which was unfavourable for germination of uredospores, formation of appressoria and penetration while average temp. $\left(20.50^{\circ} \mathrm{C}\right)$ was suitable (15$20^{\circ} \mathrm{C}$; Singh et al., 2002)for overall development of LR fungus. In March 2019 average relative humidity and average temp. were remained $40.09 \%$ and $24.90^{\circ} \mathrm{C}$ (Table 1) respectively which were also not suitable for pustule formation. Therefore, LR was not observed in wheat crop during 2018-19 in Satna district of M.P. In February 2020, total winter rainfall $(21 \mathrm{~mm})$ from western disturbance has occurred in third week on two consecutive days (20 and 21Feb.) which could bring uredospores of LR. The total period of leaf wetness has also increased for 4-5 days due to cloudiness after rainfall. In fourth week of February 2020 mean mim., mean max. and average temp. were $15.43^{\circ} \mathrm{C}, 28.28^{\circ} \mathrm{C}, 21.85^{\circ} \mathrm{C}$ respectively and Mean max. and average $\mathrm{RH}$ were $89.57 \%$ 64.14\% respectively (Table 1) became suitable for growth of germ tube, appressoria formation and penetration (according to Singh et al., 2002).Further, the weather of March 2020 (table1) i.e., temp. and $\mathrm{RH}$ became optimum for pustule formation and sporulation. Therefore, LR was observed in most of the wheat varieties (Table 2) grown in the experimental field.

LR caused by Puccinia recondita Rox. Ex Desm.is very destructive pandemic disease of wheat crop which not only reduce the crop yield but also responsible for socio-economic instability. The present study was conducted to study the role of weather factors and to work out the relationship of LR disease development with the weather factors.

Relative humidity, air temperature and precipitation are critical causative factors to the infection and progress for LR in winter wheat (Junk et al., 2016). 
Table.1 Meteorological data of February and March 2019 and 2020

\begin{tabular}{|c|c|c|c|c|c|c|c|c|c|}
\hline $\begin{array}{l}\text { S. } \\
\text { No. }\end{array}$ & Month \& & year & $\begin{array}{c}\text { Mean } \\
\text { min.Temp }\end{array}$ & $\begin{array}{c}\text { Mean } \\
\text { max.Temp }\end{array}$ & $\begin{array}{c}\text { Average } \\
\text { Temp. }\end{array}$ & $\begin{array}{c}\text { Mean } \\
\text { mim. } \\
\text { RH }\end{array}$ & $\begin{array}{c}\text { Mean } \\
\text { max. } \\
\text { RH }\end{array}$ & $\begin{array}{c}\text { Average } \\
\text { RH }\end{array}$ & $\begin{array}{l}\text { Rainfall } \\
\text { (in } \\
\text { mm.) }\end{array}$ \\
\hline \multirow[t]{3}{*}{1.} & \multirow{3}{*}{$\begin{array}{c}\text { February } \\
2019\end{array}$} & & $11.56^{\circ} \mathrm{C}$ & $29.44^{\circ} \mathrm{C}$ & $20.50^{\circ} \mathrm{C}$ & $18.36 \%$ & $44.57 \%$ & $31.46 \%$ & 2.75 \\
\hline & & $\begin{array}{c}\text { III } \\
\text { Week }\end{array}$ & 11.96 & 28.30 & 20.13 & 11.28 & 28.57 & 19.92 & 2.75 \\
\hline & & $\begin{array}{c}\text { IV } \\
\text { Week }\end{array}$ & 11.16 & 30.59 & 20.88 & 25.45 & 60.57 & 43.00 & - \\
\hline \multirow[t]{4}{*}{2.} & \multirow{4}{*}{$\begin{array}{c}\text { March } \\
2019\end{array}$} & & $18.64^{\circ} \mathrm{C}$ & $31.15^{\circ} \mathrm{C}$ & $24.90^{\circ} \mathrm{C}$ & $31.14 \%$ & $49.05 \%$ & $40.09 \%$ & - \\
\hline & & $\begin{array}{c}\text { I } \\
\text { Week }\end{array}$ & 17.31 & 28.23 & 22.77 & 26.30 & 55.47 & 40.88 & - \\
\hline & & $\begin{array}{c}\text { II } \\
\text { Week }\end{array}$ & 18.51 & 31.95 & 25.23 & 34.36 & 46.46 & 40.41 & - \\
\hline & & $\begin{array}{c}\text { III } \\
\text { Week }\end{array}$ & 20.12 & 33.27 & 26.70 & 32.78 & 45.22 & 39.00 & - \\
\hline \multirow[t]{3}{*}{3.} & \multirow{3}{*}{$\begin{array}{c}\text { February } \\
2020\end{array}$} & & ${ }_{13.93^{\circ}} \mathrm{C}$ & $28.64^{\circ} \mathrm{C}$ & $21.28^{\circ} \mathrm{C}$ & $39.21 \%$ & $85.64 \%$ & $62.42 \%$ & 21 \\
\hline & & $\begin{array}{c}\text { III } \\
\text { Week }\end{array}$ & 12.43 & 29.00 & 20.71 & 31.71 & 81.71 & 56.71 & 21 \\
\hline & & $\begin{array}{c}\text { IV } \\
\text { Week }\end{array}$ & 15.43 & 28.28 & 21.85 & 46.71 & 89.57 & 68.14 & - \\
\hline \multirow[t]{4}{*}{4.} & \multirow{4}{*}{$\begin{array}{c}\text { March } \\
2020\end{array}$} & & $16.52^{\circ} \mathrm{C}$ & $29.85^{\circ} \mathrm{C}$ & 23.18 $^{\circ} \mathrm{C}$ & $39.09 \%$ & $84.66 \%$ & $61.87 \%$ & 20 \\
\hline & & $\begin{array}{c}\text { I } \\
\text { Week }\end{array}$ & 16.71 & 30.42 & 23.56 & 46.85 & 87.28 & 67.06 & 1 \\
\hline & & $\begin{array}{c}\text { II } \\
\text { Week }\end{array}$ & 17.00 & 29.43 & 23.21 & 38.00 & 87.00 & 62.50 & 19 \\
\hline & & $\begin{array}{c}\text { III } \\
\text { Week }\end{array}$ & 15.85 & 29.71 & 22.78 & 32.42 & 79.71 & 56.06 & - \\
\hline
\end{tabular}

Table.2 Wheat varieties evaluated against leaf rust disease

\begin{tabular}{|c|c|c|c|c|c|}
\hline S. No. & Name of varieties & $\begin{array}{c}\text { Year of release } \\
\text { Source- }\end{array}$ & \multicolumn{2}{|c|}{$*$ Disease incidence } & \multirow{2}{*}{ ** } \\
\cline { 5 - 6 } & & $2018-19$ & $2019-20$ & \\
\hline iiwbr.org.in & & & & \\
\hline 2. & HI 1605 (PusaUjala) & 2017 & $1(0 \%)$ & $5(12-25 \%)$ & $\mathrm{R}$ \\
\hline $\mathbf{3 .}$ & HD 4728 (PusaMalwi) & 2016 & $1(0 \%)$ & $1(0 \%)$ & $\mathrm{R}$ \\
\hline $\mathbf{4 .}$ & HI 8737 (Pusa Anand) & 2015 & $1(0 \%)$ & $1(0 \%)$ & $\mathrm{R}$ \\
\hline $\mathbf{5 .}$ & HW 3382 & 2015 & $1(0 \%)$ & $4(6-12 \%)$ & $\mathrm{T}$ \\
\hline $\mathbf{6 .}$ & HD (Pusa Mangal) & 2013 & $1(0 \%)$ & $2(0-3 \%)$ & $\mathrm{R}$ \\
\hline $\mathbf{7 .}$ & JW 32967 & 2011 & $1(0 \%)$ & $6(25-50 \%)$ & $\mathrm{R}$ \\
\hline $\mathbf{8 .}$ & GW 3288 & 2011 & $1(0 \%)$ & $2(0-3 \%)$ & $\mathrm{T}$ \\
\hline $\mathbf{9 .}$ & JW 3211 & 2010 & $1(0 \%)$ & $4(6-12 \%)$ & $\mathrm{R}$ \\
\hline
\end{tabular}




\begin{tabular}{|c|c|c|c|c|c|}
\hline 10. & MP 1201 & 2010 & $1(0 \%)$ & $6(25-50 \%)$ & $\mathrm{R}$ \\
\hline 11. & MP 1215 & 2010 & $1(0 \%)$ & $5(12-25 \%)$ & $\mathrm{R}$ \\
\hline 12. & JW 1203 & 2009 & $1(0 \%)$ & $4(6-12 \%)$ & - \\
\hline 13. & HD 2932 & 2008 & $1(0 \%)$ & $7(50-75 \%)$ & $\mathrm{R}$ \\
\hline 14. & MP 1202 & 2008 & $1(0 \%)$ & $7(50-75 \%)$ & - \\
\hline 15. & HI 8627 (Malav Kirti) & 2007 & $1(0 \%)$ & $2(0-3 \%)$ & $\mathrm{R}$ \\
\hline 16. & GW 366 & 2007 & $1(0 \%)$ & $1(0 \%)$ & $\mathrm{R}$ \\
\hline 17. & MP 1142 & 2007 & $1(0 \%)$ & $3(3-6 \%)$ & - \\
\hline 18. & HI 1531 (Harshita) & 2006 & $1(0 \%)$ & $1(0 \%)$ & $\mathrm{R}$ \\
\hline 19. & Raj 3777 & 2006 & $1(0 \%)$ & $5(12-25 \%)$ & - \\
\hline 20. & HD 2864 (Urja) & 2005 & $1(0 \%)$ & $2(0-3 \%)$ & HR \\
\hline 21. & JW 3020 & 2004 & $1(0 \%)$ & $5(12-25 \%)$ & $\mathrm{R}$ \\
\hline 22. & HI 1500 (Amrita) & 2003 & $1(0 \%)$ & $2(0-3 \%)$ & $\mathrm{R}$ \\
\hline 23. & MP 4010 & 2003 & $1(0 \%)$ & $4(6-12 \%)$ & $\mathrm{R}$ \\
\hline 24. & GW 322 & 2002 & $1(0 \%)$ & $2(0-3 \%)$ & HR \\
\hline 25. & MP 1106 & 2002 & $1(0 \%)$ & $5(12-25 \%)$ & $\mathrm{R}$ \\
\hline 26. & HI 1418 & 2000 & $1(0 \%)$ & $3(3-6 \%)$ & $\mathrm{R}$ \\
\hline 27. & HI 1454 & 2000 & $1(0 \%)$ & $6(25-50 \%)$ & $\mathrm{R}$ \\
\hline 28. & HI 8498 (Malav Shakti) & 1999 & $1(0 \%)$ & $1(0 \%)$ & $\mathrm{R}$ \\
\hline 29. & UP2425 & 1999 & $1(0 \%)$ & $7(50-75 \%)$ & R-YR \\
\hline 30. & JW 273 & 1998 & $1(0 \%)$ & $6(25-50 \%)$ & $\mathrm{R}$ \\
\hline 31. & JWS 17 & 1997 & $1(0 \%)$ & $7(50-75 \%)$ & $\mathrm{R}$ \\
\hline 32. & Raj 3765 & 1996 & $1(0 \%)$ & $3(3-6 \%)$ & - \\
\hline 33. & PBW 343 & 1996 & $1(0 \%)$ & $7(50-75 \%)$ & - \\
\hline 34. & UP 2338 & 1995 & $1(0 \%)$ & $7(50-75 \%)$ & - \\
\hline 35. & HI 784 & 1984 & $1(0 \%)$ & $3(3-6 \%)$ & $\mathrm{R}$ \\
\hline 36. & Lok 1 & 1982 & $1(0 \%)$ & $6(25-50 \%)$ & $\mathrm{R}$ \\
\hline 37. & WH 147 & 1978 & $1(0 \%)$ & $8(75-87 \%)$ & - \\
\hline 38. & C 306 & 1969 & $1(0 \%)$ & $6(25-50 \%)$ & $\mathrm{S}$ \\
\hline 39. & Sonalika & 1969 & $1(0 \%)$ & $2(0-3 \%)$ & $\mathrm{R}$ \\
\hline 40. & UnnatHalna & UN & $1(0 \%)$ & $9(87-94 \%)$ & - \\
\hline 41. & MP 1132 & UN & $1(0 \%)$ & $5(12-25 \%)$ & - \\
\hline 42. & MP 1133 & UN & $1(0 \%)$ & $8(75-87 \%)$ & - \\
\hline 43. & JW 1105 & UN & $1(0 \%)$ & $8(75-87 \%)$ & - \\
\hline 44. & JW 2030 & UN & $1(0 \%)$ & $4(6-12 \%)$ & - \\
\hline 45. & Research Thunder & UN & $1(0 \%)$ & $4(6-12 \%)$ & - \\
\hline 46. & HIPW 168 & UN & $1(0 \%)$ & $8(75-87 \%)$ & - \\
\hline 47. & JW 322 & UN & $1(0 \%)$ & $6(25-50 \%)$ & - \\
\hline 48. & Paigambari & Local & $1(0 \%)$ & $7(50-75 \%)$ & - \\
\hline 49. & Bansi & Local & $1(0 \%)$ & $4(6-12 \%)$ & - \\
\hline 50. & Sharwati & Local & $1(0 \%)$ & $7(50-75 \%)$ & - \\
\hline
\end{tabular}

*Estimated disease incidence $* *$ Leaf rust resistance status at the time of variety release, $\mathrm{R}=$ Resistant, $\mathrm{HR}=$ Highly Resistant, $\mathrm{YR}=$ Resistant to Yellow Rust, $\mathrm{S}=$ Susceptible, VR= Very Resistant, MR= Moderately Resistant, MS= Moderately Susceptible, VS= Very Susceptible, UN=Un Notified 
Fig.1 Uredia on the leaf blade

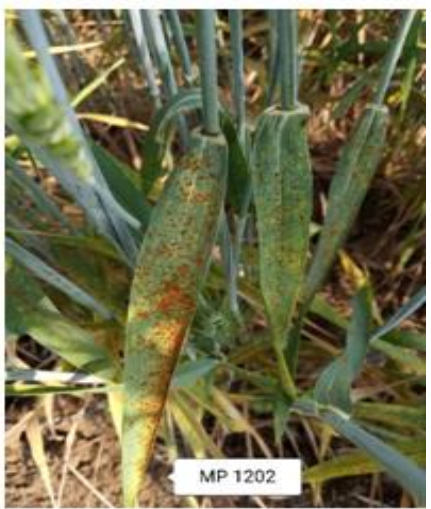

Fig.2 Uredospores

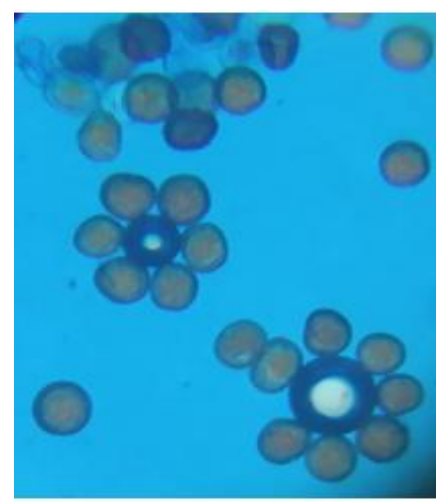

Fig.3 Telia on the lower surface

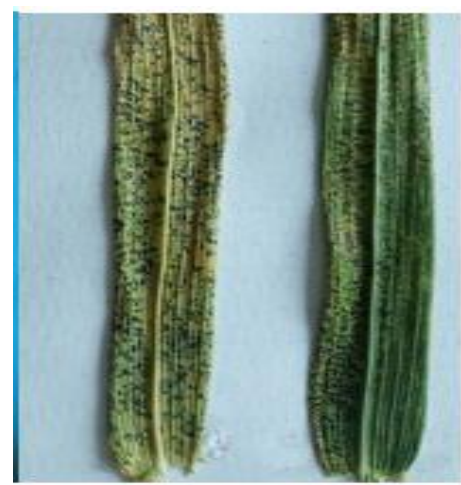

The germination of uredospores of LR ranges from $2-30^{\circ} \mathrm{C}$ (best at $20^{\circ} \mathrm{C}$ ), the formation of appressoria best at $15-20^{\circ} \mathrm{C}$, penetration at 10 $30^{\circ} \mathrm{C}$ (opt. at $20^{\circ} \mathrm{C}$ ), growth at $2-35^{\circ} \mathrm{C}$ (opt. $25^{\circ} \mathrm{C}$ ) and sporulation at $10-35^{\circ} \mathrm{C}$ (best at $25^{\circ} \mathrm{C}$ ) were observed(Singh et al., 2002). The analysis of direct weather data revealed the association of LR severity with a night temperature of $<14.25 \mathrm{C}$ while the estimated dataset showed that its severity is better explained by the dew point temperature of $<13.7$ and a mean temp. of $<19.06 \mathrm{C}$ (Victor et al., 2020).

LR developed optimally at temp. between 59 $\& 71^{\circ} \mathrm{F}$ and the disease will progress until the temperatures are above $80^{\circ} \mathrm{F}$, infection is completed in 6-8 hrs. and uredospores are capable of causing secondary spread of the disease in 7-10 days (Marsalis, and Goldberg, 2017). Leaf wetness and RH are other factors which are responsible for LR development. A nearly optimum temperatures and leaf wetness period of 6 hours results in $60-65 \%$ of pustule formation within 12 to $24 \mathrm{hrs}$ wetness period (Stuckey and Zadoks 1989). Favourable weather conditions (temperature, $\mathrm{RH}$, rainfall and cyclone) play a crucial role in long distance spread and epiphytotic. In the present study the disease was favoured by moderate temperature and high humidity for a longer period i.e., from the last week of
February to third week of March during crop season 2019-20 (Table 1). Satna had the optimum weather conditions where favourable temperature, RH, leaf wetness and cyclone (western disturbance) were prevailed. Weather data of fourth weeks of February 2020 (table 1) i.e., mean mim., max. and average temp. $\left(15.43,-28.28\right.$ and $21.85^{\circ} \mathrm{C}$ respectively), mean mim., max. and average RH (46.71, 89.57 and $68.14 \%$ respectively) and winter rainfall $(21 \mathrm{~mm}$.) favoured the disease infection through germination of uredospores, formation of appressoria and penetration of germ tube, as low temperature and humid conditions are required for successful infection establishment (Stubbs et al., 1986). Further, the weather data of three weeks of March 2020 i.e., mean mim., max. and average temp. (16.52, 29.85 and $23.18^{\circ} \mathrm{C}$ respectively), mean mim., max. and average RH (39.09, 84.66 and $61.87 \%$ respectively) and winter rainfall $(20 \mathrm{~mm}$.) favoured the disease development through growth and sporulation of fungus. The same impact of epidemiological factors on the development of Puccinia recondita Rox. Ex Desm. on Wheat was observed in Pakistan (Riaz et. al. 2013). Most of wheat varieties grown during the experiment were become susceptible for LR disease due to favourable weather for $L R$ fungus. For LR development, temperature ranging between $10-30^{\circ} \mathrm{C}$ (Singh et al., 
2002), 7-10 days period at optimum and constant temperature from spore germination to sporulation and spores can be reached at maximum in about 4 days at $20^{\circ} \mathrm{C}$ (Marsalis, and Goldberg, 2017; Stubbs et. al. 1986). Rainfall in February played a significant role in spreading the inoculum from south through western disturbance. Dissemination of LR from southern foci to central India is reported to be associated with cyclonic rains (Nagarajan and Singh 1973, 1974). It has also been observed that the amount of precipitation and number of rainy days are more in epidemic than non-epidemic years (Nagarajan and Joshi 1978a) and the present experiment also justified these conditions in LR development. Temperature rise above normal and increased humidity will predispose the crop to severe LR infection and encourage pathogen.

The LR disease of wheat is devastating as its uredospores spread by air currents over long distances and other weather factors like moderate temp., leaf wetness, RH and winter rainfall are also important significantly. It has resulted in failure of crop resistance and a considerable loss to wheat production. In present experiment most of wheat varieties were found very susceptible, susceptible and moderately susceptible. It is concluded that the deterioration in resistance against LR is due to favourable weather conditions, evolution of new races of LR fungus or continuous growing of the high yielding varieties for a long time or due to combined effect of these all factors. Since, high yielding varieties have remained popular among the farmers as these are cost effective and environmentally safe but these varieties are more prone to diseases. Because, weather cannot be controlled by the farmers and they do not follow any management method as protective or curative in their standing wheat crop at the time of disease outbreak therefore, farmers can grow these resistant varieties for riskless and constant production even in the favourable weather conditions for the LR disease during the cropping season and the immune \& very resistant lines can also be used in breeding programs.

\section{Acknowledgments}

I acknowledge the AKS University, Satna, M.P., India for undertaking the different activities of research presented in this manuscript.

\section{References}

Bahadur P., Singh D. V. and Srivastava K. D. 1994. Management of wheat rusts. A revised strategy for gene deployment. Indian Phytopath. 47:41.

Chester Kenneth S. 1950. Plant disease losses: their appraisal and interpretation. Plant Dis. Rep., Suppl.193:190-362.

CABI 2012. Disease resistance in wheat. CABI Wallingford, Oxford shire, Cambridge, MA, USA. I edition.

Horsfall J. G., and Barratt, R. W. 1945. An improved grading system for measuring plant diseases. Phytopathology. 35, 655.

John Colhoun 1973. Effects of environmental factors on plant disease. Annual Review of Phytopathology. Vol. 11:343-364.

Joshi L. M., Saari E. E., Gera S. D. and Nagarajan R. 1974. Survey and epidemiology of wheat rust in India. in: Current Trends in Plant Pathology. Published by Prof. S. N. Das Gupta. Birthday celebration committee, Lucknow, pp 151-159.

Joshi L. M., Singh D. V. and Srivastava K. D. 1984a. Fluctuations in the incidence of rusts and other wheat diseases during past decade and strategies for their containment. 23rd All India Wheat Research Workers Workshop (ICAR) held at Kanpur Aug. 1984.

Joshi L. M. 1976. "Recent contributions towards epidemiology of wheat rust in India". Indian Phytopath.29: 1-16.

Joshi L. M., Renfro B. L., Saari E. E., Wilcoxson R. D. and Raychaudhuri S.P. 1970. Rust and smut diseases of wheat in India. Plant Dis. 
Repot. 5: 391-394.

Joshi L. M., Singh D. V. and Srivastava K. D. 1985. "Status of rust and smuts in India". Rachis. 4: 10-16.

Junk J., Kouadio L., Delfosse P. and El Jarroudi M. 2016. Effects of regional climate change on brown rust disease in winter wheat. Climatic Change, 135(3-4), 439-451.

Marsalis M. A. and Goldberg N. P. 2017. Leaf, stem and strip rust diseases of wheat. NMSU.

McCartney HA (1997) The influence of environment on the development and control of disease. In: Rechcigl J (ed) Environmentally Safe Approaches to Crop Disease Control (pp 3-31) CRC Press, Bocan Ratan, Florida, USA.

Mehrotra, R. S. and Aggerwal, A. 2014. Rusts. Plant Pathology, pp440-441. Second Edition, McGraw Hill Education (India) Private Limited, New Delhi.

Muhammad S., Khan A. I., Rehman A., Awan F. S. and Rehman A. 2015. Screening of leaf rust resistance and association of leaf rust with epidemiological factors in wheat (Triticum aestivum L.). Pak. J. Agri. Sci. 52(3): 691-700.

Nagarajan S. and Joshi L. M. 1978a. Epidemiology of brown and yellow rusts of wheat over North India. II. associated meteorological conditions. Plant Dis. Reptr. 62: 186-188.

Nagarajan S. and Singh H. 1973. Satellite television cloud photography as a possible tool to forecast plant disease spread. Curr. Sci. 42: 273-274.

Nagarajan S. and Singh H. 1974. Satellite television cloud photography-a new method to study wheat rust dissemination. Indian J. Genet. 34A: 486-490.

Nathan Cobb A. 1892. Contribution to an economic knowledge of the Australian rusts (uredineae). Agr. Goz. N. S. Wales, 3: 60-68.

Peterson R. F, Campbell A. B. and Hannah A. E. 1948. A diagrammatic scale for estimating rust intensity on leaves and stems of cereals. Canadian J. Res. 26 (Section C): 496-500.

Riaz A., Riaz A., Rattu A. U. R., Tahir M. I. and Azeem M. 2013. Impact of Epidemiological Factors on Development of Puccinia triticina Sp. tritici on Wheat in Pakistan. Journal of Biology, Agriculture and Healthcare.3(19): 50-61.

Singh R. P., Huerta-Espino J. and Roelfs A. P. 2002. The wheat rusts. In Bread wheat. Improvement and production. (eds. B. C. Curtis, S Rajaram, H. Góme Macpherson). 227-248. (Food and Agriculture Organization of the United Nations: Rome).

Singh T. B. and Tiwari A. N. 2001. Role of weather conditions in the development of folior diseases of wheat under Tarai conditions of North western India. Plant Dos. Res. 16;173-178.

Sleeman, W. H. 1839. "Extracts from major Sleeman's diary”. Trans. Hort. Soc. India6: 79-87.

Stubbs R. W., Prescott J. M., Saari E. E. and Dubin H. J. 1986. Cereal disease methodology manual. 46. Mexico, DF, CIMMYT.

Stuckey R. E. and Zadoks J. C. 1989. Effect of interrupted leaf wetness period on pustule development of Puccinia recondite f. sp. tritici on wheat. Eur. J. Plant Pathol. 95(1): 175.

Victor M. Rodríguez-Moreno Alejandro Jiménez-Lagunes Juan Estrada-Avalos Jorge E. Mauricio-Ruvalcaba José S. Padilla-Ramírez. 2020. Weather-data-based model: an approach for forecasting leaf and stripe rust on winter wheat. Meteorol Appl.27: e1896.

\section{How to cite this article:}

Doomar Singh. 2021. Role of Weather Factors and Wheat Varieties on the Occurrence of Leaf Rust of Wheat in Satna, M.P. India. Int.J.Curr.Microbiol.App.Sci. 10(05): 463-471. doi: https://doi.org/10.20546/ijcmas.2021.1005.054 